\title{
Identity of Organizational Conflict Framework: Evaluating Model Factors Based on Demographic characteristics in Iran
}

\author{
Kaveh Hasani ${ }^{1}$, Saeed Sadeghi Boroujerdi ${ }^{2}$, Saman Sheikhesmaeili, ${ }^{3}$ Tayebeh Aeini ${ }^{4}$ \\ ${ }^{1}$ Young Researchers and Elite Clubs, Sanandaj Branch, Islamic Azad University of Sanandaj (Iran) \\ ${ }^{2}$ Department of Physical Education, University of Kurdistan, Sanandaj (Iran) \\ ${ }^{3}$ Central Tebran Branch, Islamic Arad University, Tehran (Iran) \\ ${ }^{4}$ Human Science Branch, Islamic Azad University, Sanandaj (Iran) \\ kaveh.bhh@gmail.com,sboromjerdi@uok.ac.ir,_Sheikhesmaeili@gmail.com,tiba.aeini@gmail.com
}

Received: December 2013

Accepted: September 2014

\section{Abstract:}

Purpose: The purpose of this study was to Identity of organizational conflict framework: Evaluating model factors based on demographic characteristics in Iran.

Design/methodology/approach: Research method is descriptive - applied. The statistical population includes all of the employees in Iran's Azad Universites with 600 individuals at the time of the study and statistical sample included 234 individuals who were selected using Morgan table. Beside this study, descriptive and inferential statistics were used. Also, reliability approved through Cronbach alpha (0.87). Then, to detect the dimensions causes of organizational conflict, factor analysis in line with the main components was used. Through exploratory analysis, ten principal factors identified. Thereafter, confirmatory factor analysis reconfirmed these factors.

Findings and originality/value: The results of study showed that there is no significant difference between the causes of organizational conflict based on the gender. Also, there are significant differences among the causes of organizational conflict based on the variables of age, education and work experience. 
Research limitations/implications: We adopt a cross sectional research design and as a result inferences regarding causality cannot be drawn. Future studies following a longitudinal design could provide a more dynamic perspective and contribute further to this stream of research.

Originality/value: A lot of researches about the conflict management styles, organizational conflict's effects, etc. are conducted by different researchers, but a handful of researches have been conducted in the field of resources and causes of organizational conflict and this is one of the reasons that it is important for researchers to address this issue.

Keywords: conflict, causes of conflict, employees, university

\section{Introduction}

Nowadays conflict is inevitable in workplaces and it is very important to manage it in a proper way to minimize the problems that might arise (Mokhtarpour, Khademi \& Mokhtarpour, 2013). Conflict is a serious problem in organizations, but conflict isn't reason for corruption in organizations of its nature. Ineffectiveness conflict management is the reason of undesirable outcomes (Kellermann, 1996; VatanKhah, Raeisi \& Kalhor, 2008). Therefore, it is necessary to explain and identify the determinants of this issue in organizations in order to properly manage them. Conflict between people are caused for several reasons, some of which include incompatible goals, different values and beliefs, ambiguity and role conflict, problems of communications, ambiguous rules, authority conflict, inconsistent evaluation and reward system, job stress, task conflict, deficiency of information system, etc., which in turn can affect the managers and staff's satisfaction (Druckman, Broome \& Korper, 1988; Salleh \& Adulpakdee, 2012). This problem and many other issues are an inevitable part of human communication in the education structures (Akhoond lotfali, Hosseini, Khankeh, Fallahi Khoshknab \& Hosseinzadeh, 2012). The existence of different people with different demographic characteristics, personality, needs, expectations and various perceptions are the cause of conflict in organizations, including educational institutions (Kellermann, 1996; Wall Jr \& Callister, 1995).

Eder and James (2002) in their study showed that variable recognition of conflicts between demographic factors is very important. Also, they found that there are significant relationships between demographic characteristics include (age, gender, income, education level) with management experience (Eder \& James, 2002). The more studies that accomplished about the relationship between conflict management styles and demographic variables Such as gender variable, have yielded inconsistent results (Cetin \& Hacifazlioglu, 2004; İslamoglu, Boru \& Birsel, 2008). Therefore, it is important to address other demographic variables such as 
education, marital status, having children, position, tenure in the current organization and the total tenure. The relationship between these demographic variables and conflict management styles has been tested while these relationships are thought to be important for improving workplace relations (İslamoglu et al., 2008). Since the universities include social systems in which all of its processes, humans and activities of the group have a vital role; it seems that they may have stress and conflict more than any other social systems (Corwin, 1969; Fisher \& Gitelson, 1983; BazarJazaeri, 1998).

The aim of social systems such as universities, create and provide the necessary resources for intellectual growth and development and help to flourish the knowledge learners and expand exceptional talents. According to the breadth of educational institutions in the Iran, there are many different problems that each resulting from the occurrence of behavioral or social changes. Human resources include managers and employees because how to determine behavior and performance of employees shows the success or failure of the predetermined goals. In this regard, performance of universities and educational centers, on the one hand and management patterns of endogenous activity on the other hand, depend on interaction between managers and educational factors by adopting suitable method of model management. In other words, we can say that the elements of transition affect teaching, especially in the educational environment and require the motivation and satisfaction of managers and employees; therefore, they utilize effective styles and methods of management to communicate favorable behavior in the university's decisions. Several studies show that type of vision, beliefs, perception and expectations of managers in the scene of training and relations with employees, can decelerate or accelerate the duties and roles of the staff (Frederickson, 1998). It is very important to note that the staff and faculty with mental problems caused by conflict and stress cannot guide students in the education. Thus, it seems that any member of the teaching forces (managers, staff, and faculty) at the university who is calm and has less stress and conflict, increases the performance of the university including academic achievement of students. On the other hand, many grievances, poor performance and lack of efficient activities cause lower performance levels and due to conflicts between managers and employees, they will not be able to know the causes and sources of conflict which underlie many of the conflicts in the organizations. In addition, demographic variables would appear to be a significant way that human beings differ in relationship to conflict resolution style (Holt \& DeVore, 2005).

Recent research has shown that the objective value conflict between educational groups is reflected at the subjective level in the form of a development of identity and consciousness around those groups (Balay, 2006; Stubager, 2009). However, the reasons that have led researcher examined this issue in educational institutes, was that conflict as a phenomenon, that more than any other topic has involved thought managers and employees. Therefore, knowledge of the causes of conflict can lead to the reduction of destructive conflict and also, conflict management in universities and similar educational units. In this regard, according to 
the points mentioned above, researcher sought to find causes of organizational conflict between managers and employees based on demographic characteristics. Therefore, the purpose of this study was to Identity of organizational conflict framework: Evaluating model factors based on demographic characteristics, including gender, age, education and work experiences on IAU of Sanandaj. Finally, the researcher seeks to find scientific answers to the following questions: Are there any significant differences among the causes of organizational conflict based on the dimension of gender? Are there any significant differences among the causes of organizational conflict based on the dimension of age? Are there any significant differences among the causes of organizational conflict based on the dimension of education? Are there any significant differences among the causes of organizational conflict based on the dimension of work experiences?

\section{The Importance and Necessity of Research}

Conflict is an integral part of human life. A quick overview and the level of the historical events show that conflict is one of the most prominent aspects of human life. So a person who says that conflict is a current issue that has preoccupied the human mind has a true claim (Havenga, 2002).

The existence of different people with the personality characteristics, needs, beliefs, expectations and different perceptions inevitably causes conflict in organizations (Parsaeian \& Arabi, 1996; Balay, 2006). People have a way of communicating, dreams, political and religious views and also have different cultural backgrounds (Freeman \& Gilbert, 1988). In different communities, the existence of these differences will lead to conflicts between individuals and groups (Kreitner \& Kinicki, 2001). Hence, the existence of differences, risks and different incentives in the employees' organizations on the one hand and sustainability organization on the principles of partnership and coordination of people and organization components on the other hand led to the inevitable organizational issue against the organizational conflict (Guetzkow \& Gyr, 1954).

Essentially, managers in organizations are forced to guide and manage the conflict and should consider an appropriate way of dealing with conflict and while the conflicts exist, they cause disorder in working relationship and decrease satisfaction of management and employees. As a result of lack of satisfaction, organizational performance will decrease dramatically (Dubrin, 2005). In summary, we can say that conflict is an inevitable fact of organizational life and it must be faced and accepted, therefore a proper way for dealing with conflict should be found and should be discussed. A lot of researches on the conflict management styles, organizational conflict's effects, etc. are conducted by different researchers, but a handful of researches have been conducted in the field of resources and causes of organizational conflict and this is one of the reasons that researchers should address this issue. 


\section{Review of the Literature}

In this section, the researcher tries to review and study the work of other researchers on the topic discussed in this article. Result study of Sorensen, Campbell, Gill and Steffen-Campbell (1995) showed that women are more inclined than men to have more sense of style, also, they founded no significant differences between women and men on the use of conflict management styles (Sorensen et al., 1995).

Johnson, Johnson, Dudley, Mitchell and Frederickson (1997) conducted a study with elementary school students by totaling 14 hours, with 25 minute periods, and reported significant differences between the experimental and control group in the knowledge of the negotiation procedure and able to apply it to real conflicts (Johnson et al., 1997).

Coleman (2003), in his study identified 50 factors affecting conflict. These factors include various aspects of the environment, relationships, processes and the outcomes (Coleman, 2003).

The result of Gordon's study (2008) showed that there is no evidence to support a correlation between gender or age and a preferred conflict management style. Also, other results indicated that the preferred conflict management style for both men and women was the integrating style (Gordon, 2008).

Kantek and Gezer (2009) in their study showed that the students preferred to use styles which produced positive results in conflict resolution and that the frequency of experiencing conflict and the feeling of success in the conflict had an effect on the choice of conflict management style. Also, they believe that it will be helpful to analyze the relationship between the causes of conflict between the student and the instructor in the practical field and the uses of conflict management styles (Kantek \& Gezer, 2009).

Srivastava (2009) in his study entitled as "organizational variables and job stress: effect of moderating variables", showed that organizational variables include (blocked career, alienation, conflict, and unfavorable work environment) had significant positive effects of job stress. Also, he found that gender moderated the effects of organizational stressors on job stress (Srivastava, 2009).

Michel, Mitchelson, Kotrba, LeBreton and Baltes (2009) in a research entitled as "A comparative test of work-family conflict models and critical examination of work-family linkages", showed that direct effects drove work-family conflict models, while indirect effects provided little incremental explanation about satisfaction outcomes (Michel et al., 2009).

Huang (2010) in his research showed that; team goal orientation and a conflict management approach moderated the relationship between task conflict and relationship conflict. Also, the 
positive relationship between task conflict and relationship conflict was weaker under conditions of higher team learning orientation and lower team performance orientation. Another result of his study showed that the positive association between task conflict and relationship conflict was also weaker among teams engaged in cooperative conflict management and were not engaged in avoiding conflict management approach (Huang, 2010).

Alzawahreh and Khasawneh (2011) in a study entitled as "Conflict Management Strategies Adopted by Jordanian Managers based on Employees ' Perceptions: the Case for the Manufacturing Industry", showed that do not have an impact on the conflict management styles regarding to the demographic variables includes; gender, level of education, and years of experience in current position (Alzawahreh \& Khasawneh, 2011).

Salleh and Adulpakdee (2012), in their study entitled as "Causes of conflict and effective methods of conflict management at Islamic secondary schools in Yala, Thailand" found that principles perceived that the main cause of conflicts occurring in school was the ambiguously defined responsibilities" and the teachers agreed that "different perception" were the major cause of conflict in school. Also, interestingly, both principals and teachers strongly agreed that the most effective method of solving conflict was to find the causes and take the proper steps for the solutions (Salleh \& Adulpakdee, 2012).

Bibi, Siraj and Nawaz (2012), in their study states that organizational scale (Basic Pay Scale), age and experience had a significant impact on the responses, Also, they state that responses of labor from both the organizations showed that there are no significant differences in interpersonal conflict, mistreatment and discrimination (Bibi et al., 2012).

Römer, Rispens, Giebels and Euwema (2012) in their study found that leaders' third-party problem-solving behavior had a buffering effect on the association between relationship conflict and conflict-related stress (Römer et al., 2012).

Wamocha, Nasongo and Injendi (2012) in a study entitled "Intervention measures in conflict management in boarding secondary schools in the western province, Kenya" showed that the concept of "conflict management" referred to an act and a process of resolving disputes among two or more parties to resolve them. The importance of the study findings was: to offer greater insight to the administrators of secondary schools on the intervention measures in conflict management in boarding secondary schools. Also, the findings of their study maybe help to educate policy makers, managers of schools, head teachers and teachers give guidance for the proper use of punishment in conflict management (Wamocha et al., 2012). And finally, Mokhtarpour et al. (2013) in a study showed, there were a significant relationship among the principals' level of income and the use of collaboration and accommodation styles. Also, there was a statistically significant difference between gender and the use of the fivefold approach of the domination style. They showed that overall, there was a significant relationship between the principal demographic characteristics and the conflict management style choices. 


\section{Research Hypotheses}

- There is a significant difference between the causes of organizational conflict based on the variable of gender.

- There is a significant difference between the causes of organizational conflict based on the variable of age.

- There is a significant difference between the causes of organizational conflict based on the variable of education.

- There is a significant difference between the causes of organizational conflict based on the variable of work experience.

\section{The Research Method}

The purpose of this study was to Identity of organizational conflict framework: Evaluating model factors based on demographic characteristics. Research method is descriptive - applied. The statistical population includes all the employees of IAU of Sanandaj in Iran and their number at the time of the study was 600 individuals and statistical sample using Morgan table was selected to be 234 (Krejcie \& Morgan, 1970).

\subsection{Research variables}

Considered variables in this study consisted of individual characteristics including gender, age, education, work experience and dimensions of organizational conflict which is including (incompatible goals, different values and beliefs, ambiguity and role conflict, problems of communications, ambiguous rules, authority conflict, inconsistent evaluation and reward system, job stress, Task conflict, deficiency in information systems).

\subsection{Measurement tools}

To measure the research variables, one researcher-made questionnaire was used which adapted from; Mcshane and Travaglione's questionnaire (2003) for conflict sources; Eliot's questionnaire (1995) for job stress; Hellriegel, Slocum and Woodman's questionnaire (1983) for ambiguity of roles and contrast; Dubrin's questionnaire (1985) for job conflict and questionnaires contained 38 questions. Also, questionnaires had a five-choice scale (very low, low, medium, high, and very high). 


\subsection{Validity and Reliability of Questionnaires}

The validity of the used questions, including the validity and accuracy of the questionnaires' questions, was confirmed by a number of experts and masters and the standardization of the questionnaires and their normalization in other studies provided validity of the test. To calculate the reliability of test questions, Cronbach alpha test was used and the obtained alpha for the questionnaire was 0.87 respectively, and they were confirmed in (0.001) level. Also, to measure the efficiency of sampling, KMO (Kaiser- Meyer- Olkin) test was used. KMO equaled in 0.852 which implied the sampling's efficiency. To detect whether data are able to be factor Analysis or not, the Bartlett's test was utilized. The value was $2.96(p<0.01)$. Varimax orthogonal rotation and main component's method were dedicated to factor analysis. Through exploratory factorial analysis, 10 main factors were identified, and via confirmatory factorial analysis, these 10 factors were re-confirmed.

\subsection{Methods of Statistical Analysis}

Statistical methods of this research involved factor analysis, confirmatory factorial analysis and descriptive statistics were used to describe the research data and in inferential statistics, Kolmogorov-Smirnov test, t- test and One-way ANOVA were used. The significance level of this study was considered to be 0.05 and SPSS and LISREL software were applied to analyze data.

\section{Results}

\subsection{Results of Descriptive Statistics}

Respondents' descriptive information on the study, in terms of Gender, Age, education and work experience, is explained in Table 1.

\begin{tabular}{|c|c|c|c|c|c|c|c|}
\hline \multicolumn{2}{|c|}{ Work Experience } & \multicolumn{2}{c|}{ Education } & \multicolumn{2}{c|}{ Gender } \\
\hline Percent & Level & Percent & Level & Percent & Level & Percent & Level \\
\hline 2.27 & Under 5 years & 0 & Diploma & 10.55 & Under 30 years & & \\
\hline 22.73 & $5-10$ & 31.5 & Up diploma & 50.36 & $30-40$ & 67.7 & Male \\
\hline 38.64 & $10-15$ & 30.4 & Associate of arts & 25.9 & $40-50$ & & \\
\hline 4.55 & $15-20$ & 28.4 & MA & 13.09 & Up 50 years & 32.3 & Female \\
\hline 31.82 & Up 20 years & 9.7 & PhD & & & 100 & Total \\
\hline 100 & Total & 100 & Total & 100 & Total & 10 \\
\hline \multicolumn{7}{|c|}{ The total number of samples: 234} \\
\hline
\end{tabular}

Table 1. Descriptive statistics of the demographic variables 
According to Table 1, results based on the gender of the respondents in the questionnaire indicate that most respondents are male employees with $67.7 \%$ and few respondents are female employees with $32.3 \%$. Based on the questionnaire, $10.55 \%$ of the respondents were under 30 years, $50.36 \%$ were between 30 and 40 years, $25.9 \%$ were between 40 and 50 years and $13.09 \%$ of respondents were over 50 years old. The education level of $31.5 \%$ of respondents is a high school degree, $30.4 \%$ have a bachelor's degree, and $28.4 \%$ have master's degrees and $9.7 \%$ held the doctoral degrees which indicated educational degree of the samples i.e. associate, bachelor and master's degree, and it can be inferred that subjects with more knowledge filled out the questionnaires and based on the work experience, respondents of the questionnaire including $2.27 \%$ were below 5 years, $22.73 \%$ were between 5 and 10 years, 38.64\% were between 10 and 15 years, $4.55 \%$ were between 15 and 20 years and $31.82 \%$ were over 20 years as shown in Table 1 . Also results of descriptive statistics of the dimensions of the causes of organizational conflict are shown in Table 2.

\begin{tabular}{|l|c|c|c|c|c|}
\hline Dimensions of Organizational Conflict & N & Min & Max & Mean & Std. Deviation \\
\hline Incompatible goals & 234 & 7 & 17 & 13.124 & 2.227 \\
\hline Different values and beliefs & 234 & 3 & 14 & 7.894 & 1.808 \\
\hline Ambiguity and role conflict & 234 & 7 & 18 & 12.635 & 2.138 \\
\hline Problems of communications & 234 & 5 & 62 & 11.179 & 4.119 \\
\hline Ambiguous rules & 234 & 4 & 20 & 11.230 & 3.418 \\
\hline Authority conflict & 234 & 4 & 13 & 8.479 & 1.846 \\
\hline Inconsistent evaluation and reward system & 234 & 4 & 16 & 9.792 & 3.007 \\
\hline Job stress & 234 & 4 & 20 & 11.645 & 3.443 \\
\hline Task conflict & 234 & 4 & 19 & 9.728 & 2.672 \\
\hline Deficiency in information system & 234 & 4 & 20 & 11.161 & 3.984 \\
\hline
\end{tabular}

Table 2. Descriptive statistics of the Dimensions of Organizational Conflict

According to the results shown in Table 2, maximum score corresponds to (problems of communications) with a score of (62) and a minimum score corresponds to (Different values and beliefs) with a score of (3). Average maximum corresponds to (incompatible goals) with a score of 13.124 and average minimum corresponds to (different values and beliefs) with a score of 7.894. Also maximum standard deviation corresponds to (problems of communications) with a score of 4.119 and minimum standard deviation corresponds to (different values and beliefs) with a score of 1.808 . 


\subsection{Results of factor analysis}

Results of factor analysis indicated that there were ten factors having the value of more than 1. Total Variance Explained table and Scree plot revealed that a general factor existed appointing the highest variance. These results are in accordance with our theory stating the presence of ten factors and also the link of these factors with causes of organizational conflict. From the exploratory factorial analysis, by applying Varimax rotation and main component's method, 10 factors with the value of more than 1 were obtained. Table 3 displays the results of this analysis. Factors 1 to 10 gave the following variances, respectively: 24.181, 6.445, 5.263, $4.261,3.991,3.643,3.376,3.095,2.933$, and 2.829. The sum of these variances is 60.017 .

\begin{tabular}{|c|c|c|c|c|c|c|c|c|c|}
\hline \multirow{2}{*}{ Factors } & \multicolumn{3}{|c|}{ Initial Eigenvalues } & \multicolumn{3}{|c|}{$\begin{array}{l}\text { Extraction Sums of Squared } \\
\text { Loadings }\end{array}$} & \multicolumn{3}{|c|}{$\begin{array}{l}\text { Rotation Sums of Squared } \\
\text { Loadings }\end{array}$} \\
\hline & Total & $\begin{array}{c}\% \text { of } \\
\text { Variance }\end{array}$ & $\begin{array}{c}\text { Cumulative } \\
\%\end{array}$ & Total & $\begin{array}{c}\% \text { of } \\
\text { Variance }\end{array}$ & $\begin{array}{c}\text { Cumulative } \\
\%\end{array}$ & Total & $\begin{array}{c}\% \text { of } \\
\text { Variance }\end{array}$ & $\begin{array}{c}\text { Cumulative } \\
\%\end{array}$ \\
\hline $\begin{array}{l}\text { 1. Incompatible } \\
\text { goals }\end{array}$ & 9.18 & 24.181 & 24.181 & 9.189 & 24.181 & 24.181 & 3.53 & 9.309 & 9.309 \\
\hline $\begin{array}{l}\text { 2. Different } \\
\text { values and } \\
\text { beliefs }\end{array}$ & 2.44 & 6.445 & 30.626 & 2.449 & 6.445 & 30.626 & 2.91 & 7.682 & 16.991 \\
\hline $\begin{array}{l}\text { 3. Ambiguity and } \\
\text { role conflict }\end{array}$ & 2.00 & 5.263 & 35.890 & 2.000 & 5.263 & 35.890 & 2.85 & 7.506 & 24.497 \\
\hline $\begin{array}{l}\text { 4. Problems of } \\
\text { communications }\end{array}$ & 1.61 & 4.261 & 40.151 & 1.619 & 4.261 & 40.151 & 2.74 & 7.230 & 31.727 \\
\hline $\begin{array}{l}\text { 5. Ambiguous } \\
\text { rules }\end{array}$ & 1.51 & 3.991 & 44.142 & 1.517 & 3.991 & 44.142 & 2.39 & 6.294 & 38.021 \\
\hline $\begin{array}{l}\text { 6. Authority } \\
\text { conflict }\end{array}$ & 1.38 & 3.643 & 47.784 & 1.384 & 3.643 & 47.784 & 1.80 & 4.745 & 42.765 \\
\hline $\begin{array}{l}\text { 7. Inconsistent } \\
\text { evaluation and } \\
\text { reward system }\end{array}$ & 1.28 & 3.376 & 51.160 & 1.283 & 3.376 & 51.160 & 1.78 & 4.691 & 47.456 \\
\hline 8. Job stresses & 1.17 & 3.095 & 54.255 & 1.176 & 3.095 & 54.255 & 1.64 & 4.338 & 51.794 \\
\hline 9. Task conflict & 1.11 & 2.933 & 57.188 & 1.114 & 2.933 & 57.188 & 1.60 & 4.213 & 56.007 \\
\hline $\begin{array}{l}\text { 10. Deficiency in } \\
\text { information } \\
\text { system }\end{array}$ & 1.07 & 2.829 & 60.017 & 1.075 & 2.829 & 60.017 & 1.52 & 4.010 & 60.017 \\
\hline
\end{tabular}

Table 3. Number of explaining variances 


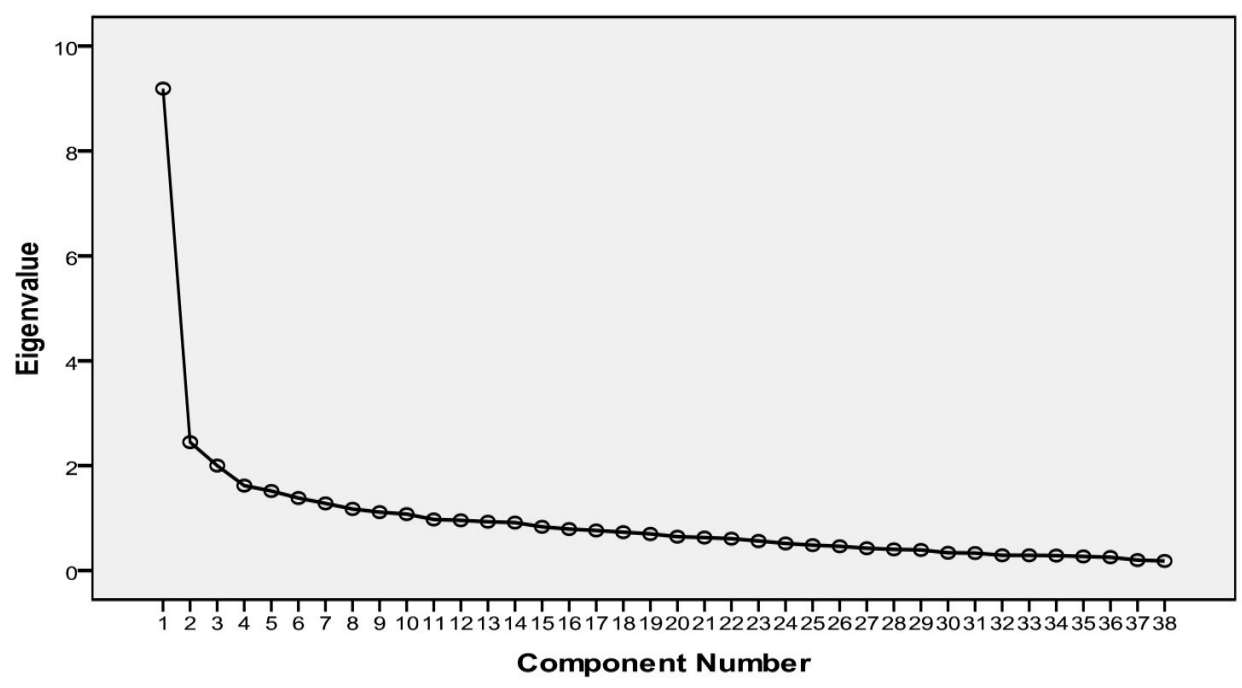

Figure 1. Scree Plot for Extracting Factors

Considering the scree plot showed the possibility of extracting 10 factors out of data. For more transparency, data were re-analyzed by Varimax rotation. The results of this analysis, involving factorial loads of varied items in every factory, are shown in Table 4. To interpret results, minimum factorial load of 0.30 was utilized which is common in factorial analyses.

In Table 4, results of factor analysis the causes of organizational conflict based on 10 main factors were shown. All of their coefficients possess high values. To determine which factors in questionnaire causes of organizational conflict would be confirmed, after performing an exploratory factorial analysis via SPSS, by using LISREL software, confirmatory factorial analysis was implemented to specify factors being confirmed. For assessing to what extent the given model fits with obtaining data, in addition to $\chi^{2}$ and critical amount of sample volume, we relied on three other fitness indices. Non-meaningful $\chi^{2}$ clarified fitness of mthe modelwith data. When the volume of sample is high, the other statistical indices show model fitness in a better way. Thus, if $\chi^{2}$ is equal to 2 or less, it indicates a proper fitness, and the volume of sample should be higher than 200. Three other important indices of fitness include: Goodness of fitness index (GFI), Comparative fitness index (CFI), and Root mean square error of approximation (RMSEA). 


\begin{tabular}{|c|c|c|c|c|c|c|c|c|c|c|}
\hline \multicolumn{11}{|c|}{ Factors } \\
\hline Questions & 1 & 2 & 3 & 4 & 5 & 6 & 7 & 8 & 9 & 10 \\
\hline 1 & 0.714 & & & & & & & & & \\
\hline 2 & 0.801 & & & & & & & & & \\
\hline 3 & 0.617 & & & & & & & & & \\
\hline 4 & 0.531 & & & & & & & & & \\
\hline 5 & & 0.725 & & & & & & & & \\
\hline 6 & & 0.512 & & & & & & & & \\
\hline 7 & & 0.441 & & & & & & & & \\
\hline 8 & & & 0.653 & & & & & & & \\
\hline 9 & & & 0.449 & & & & & & & \\
\hline 10 & & & 0.762 & & & & & & & \\
\hline 11 & & & 0.580 & & & & & & & \\
\hline 12 & & & & 0.488 & & & & & & \\
\hline 13 & & & & 0.430 & & & & & & \\
\hline 14 & & & & 0.674 & & & & & & \\
\hline 15 & & & & 0.754 & & & & & & \\
\hline 16 & & & & & 0.538 & & & & & \\
\hline 17 & & & & & 0.542 & & & & & \\
\hline 18 & & & & & 0.631 & & & & & \\
\hline 19 & & & & & 0.474 & & & & & \\
\hline 20 & & & & & & 0.436 & & & & \\
\hline 21 & & & & & & 0.708 & & & & \\
\hline 22 & & & & & & 0.492 & & & & \\
\hline 23 & & & & & & & 0.512 & & & \\
\hline 24 & & & & & & & 0.676 & & & \\
\hline 25 & & & & & & & 0.662 & & & \\
\hline 26 & & & & & & & 0.470 & & & \\
\hline 27 & & & & & & & & 0.535 & & \\
\hline 28 & & & & & & & & 0.708 & & \\
\hline 29 & & & & & & & & 0.667 & & \\
\hline 30 & & & & & & & & 0.501 & & \\
\hline 31 & & & & & & & & & 0.707 & \\
\hline 32 & & & & & & & & & 0.736 & \\
\hline 33 & & & & & & & & & 0.556 & \\
\hline 34 & & & & & & & & & 0.679 & \\
\hline 35 & & & & & & & & & & 0.673 \\
\hline 36 & & & & & & & & & & 0.783 \\
\hline 37 & & & & & & & & & & 0.857 \\
\hline 38 & & & & & & & & & & 0.800 \\
\hline
\end{tabular}

Table 4. Results of factors Analysis the causes of organizational conflict 


\begin{tabular}{|l|c|c|}
\hline \multicolumn{1}{|c|}{ Index } & Index & Reported Value \\
\hline Chi-square & $\chi^{2}$ & 115.24 \\
\hline Chi square divided by degrees of freedom & $\chi^{2} / \mathrm{df}$ & 620 \\
\hline Root mean square error of approximation & RMSEA & 0.049 \\
\hline Goodness of fitness index & GFI & 0.94 \\
\hline Adjusted goodness of fit index & AGFI & 0.93 \\
\hline Nor med fit index & NFI & 0.92 \\
\hline Non-nor med fit index & NNFI & 0.91 \\
\hline Comparative fit index & CFI & 0.93 \\
\hline P-value & p & 0.000 \\
\hline
\end{tabular}

Table 5. Fitness indexes of LISREL general model of the research conceptual framework

The higher amount of GFI and CFI would be better (e.g., higher than 0.90), because they compare the lack of fitness of a given model with an independent model; while, the lower RMSEA (e.g. Lower than 0.50) leads to better fitness of obtaining model. In a nutshell, to assess the fitness of the model, six indices are applied, including, $\chi^{2}, \chi^{2} / \mathrm{df}$ ratio, volume of sample, GFI, CFI, and RMSEA. Apart from these indices, we have used other ones. Based on GFI and p-value indices, it can be expressed that, 10 factors of causes of organizational conflict used in the given questionnaire were confirmed. 


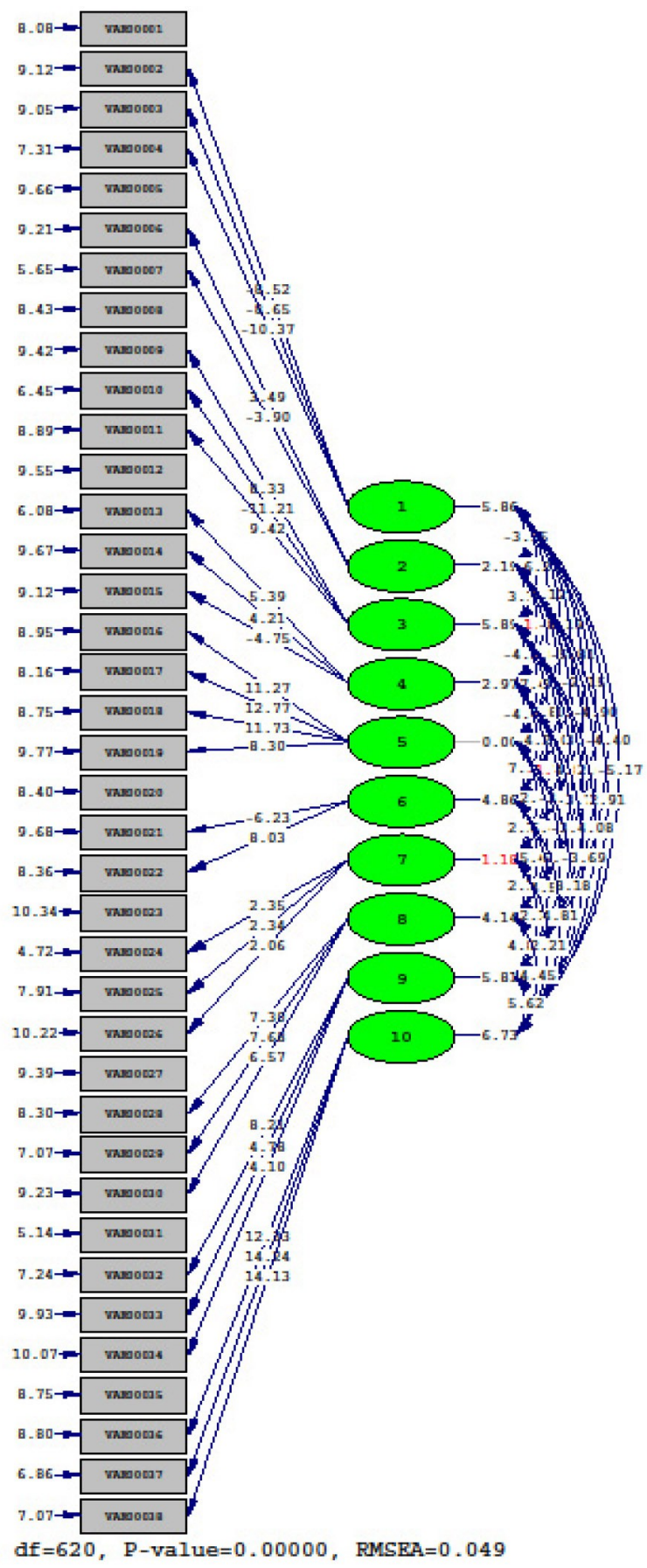

Figure 2. Model of measuring confirmation of causes of organizational conflict in questionnaire by applying confirmatory factorial analysis 


\subsection{The Analytical Results}

In order to use inferential statistics, the data normality was evaluated by Kolmogorov -Smirnov test and statistical tests were used by confirming normal data.

First Hypothesis: There is a significant difference between the causes of organizational conflict based on the variable of gender.

To compare men with women (gender) with the causes of organizational conflict, the independent t-test was used and results of these tests are presented in Table 6.

\begin{tabular}{|c|c|c|c|c|}
\hline Dimensions of Organizational Conflict & Mean difference & $T$ & df & Sig \\
\hline Incompatible goals & -0.111 & -0.334 & 232 & 0.73 \\
\hline Different values and beliefs & 0.476 & 1.823 & 232 & 0.70 \\
\hline Ambiguity and role conflict & -0.115 & 0.372 & 232 & 0.71 \\
\hline Problems of communications & -0.620 & -1.037 & 232 & 0.30 \\
\hline Ambiguous rules & -0.482 & -0.971 & 232 & 0.32 \\
\hline Authority conflict & 0.370 & 1.383 & 232 & 0.16 \\
\hline Inconsistent evaluation and reward system & -0.010 & -0.025 & 232 & 0.98 \\
\hline Job stress & -0.481 & -0.963 & 232 & 0.33 \\
\hline Task conflict & -0.548 & -1.418 & 232 & 0.15 \\
\hline Deficiency in information system & -0.942 & -1.636 & 232 & 0.10 \\
\hline
\end{tabular}

Table 6. Results of Independent t-test to compare the gender component

According to the results shown in Table 6, there is no significant difference between the causes of organizational conflict based on the variable of gender. Therefore, the researcher hypothesized that there was no significant difference between the causes of organizational conflict based on the variable of gender is rejected.

Second Hypothesis: There is a significant difference between the causes of organizational conflict based on the variable of age.

To compare the variable of age with the causes of organizational conflict, One-way ANOVA test was used and results of these tests are presented in Table 7. 


\begin{tabular}{|c|c|c|}
\hline Dimensions of Organizational Conflict & $\mathbf{F}$ & Sig \\
\hline Incompatible goals & 3.789 & 0.003 \\
\hline Different values and beliefs & 2.406 & 0.037 \\
\hline Ambiguity and role conflict & 2.355 & 0.042 \\
\hline Problems of communications & 3.638 & 0.011 \\
\hline Ambiguous rules & 2.769 & 0.037 \\
\hline Authority conflict & 2.898 & 0.036 \\
\hline Inconsistent evaluation and reward system & 2.390 & 0.039 \\
\hline Job stress & 2.562 & 0.028 \\
\hline Task conflict & 2.718 & 0.021 \\
\hline Deficiency in information system & 2.408 & 0.038 \\
\hline
\end{tabular}

Table 7. Results of One-way ANOVA for comparing the causes of Organizational Conflict with the Dimension of Age

According to the results shown in Table 7, there is a significant difference between the causes of organizational conflict based on the variable of age, and the significance level is lower than 0.05 in all variables of organizational conflict, therefore, the researcher hypothesized that there is a significant difference between the causes of organizational conflict based on the variable of age is accepted.

Third Hypothesis: There is a significant difference between the causes of organizational conflict based on the variable of education.

To compare variable of education with the causes of organizational conflict, One-way ANOVA test was used and results of these tests are presented in Table 8.

\begin{tabular}{|c|c|c|}
\hline Dimensions of Organizational Conflict & $\mathbf{F}$ & Sig \\
\hline Incompatible goals & 3.051 & 0.011 \\
\hline Different values and beliefs & 2.646 & 0.024 \\
\hline Ambiguity and role conflict & 2.562 & 0.021 \\
\hline Problems of communications & 3.240 & 0.005 \\
\hline Ambiguous rules & 3.682 & 0.002 \\
\hline Authority conflict & 4.420 & 0.000 \\
\hline Inconsistent evaluation and reward system & 2.340 & 0.033 \\
\hline Job stress & 2.268 & 0.038 \\
\hline Task conflict & 3.456 & 0.014 \\
\hline Deficiency in information system & 2.265 & 0.039 \\
\hline
\end{tabular}

Table 8. Results of One-way ANOVA for comparing the causes of Organizational Conflict with the Dimension of Education 
According to the results shown in Table 8, there is a significant difference between the causes of organizational conflict based on the variable of education and the significance level is lower than 0.05 in all variables of organizational conflict, Therefore, the researcher hypothesized that there is a significant difference between the causes of organizational conflict based on the variable of education is accepted.

Fourth Hypothesis: There is a significant difference between the causes of organizational conflict based on the variable of work experience.

To compare variable of work experience with the causes of organizational conflict, One-way ANOVA test was used and results of these tests are presented in Table 9.

\begin{tabular}{|c|c|c|}
\hline Dimensions of Organizational Conflict & $\mathbf{F}$ & Sig \\
\hline Incompatible goals & 4.164 & 0.001 \\
\hline Different values and beliefs & 2.527 & 0.022 \\
\hline Ambiguity and role conflict & 4.420 & 0.000 \\
\hline Problems of communications & 3.143 & 0.006 \\
\hline Ambiguous rules & 2.633 & 0.018 \\
\hline Authority conflict & 2.617 & 0.014 \\
\hline Inconsistent evaluation and reward system & 2.340 & 0.033 \\
\hline Job stress & 2.265 & 0.038 \\
\hline Task conflict & 2.562 & 0.028 \\
\hline Deficiency in information system & 3.638 & 0.011 \\
\hline
\end{tabular}

Table 9. Results of One-way ANOVA for comparing the causes of Organizational Conflict with the Dimension of Work experience

According to the results shown in Table 9, there is a significant difference between the causes of organizational conflict based on the variable of work experience and significance level is lower than 0.05 in all variables of organizational conflict, therefore, the researcher hypothesized that there is a significant difference between the causes of organizational conflict based on the variable of work experience is accepted.

\section{Discussion and Conclusions}

Conflict is an omnipresent feature at each one of these organizational levels. Since conflict may have functioned as well as dysfunctional consequences, need to that administrators explore various methods and techniques of conflict management. Understanding and promoting effective conflict management strategies is of paramount importance for the growth and development of any organization. Should be noted that in this line, some of the writings have 
regarded conflict as a key catalyst for positive social and organizational change. Their productive transformation towards social progress can, as a rule, only succeed when the particular ability of people and collectives to peacefully and constructively manage and resolve conflicts (Seitz, 2004; Dupuy, 2009).

The main aim of this study is to Identity of organizational conflict framework: Evaluating model factors based on demographic characteristics. The results of the data analysis showed that $67.7 \%$ of respondents were male and most of the respondents were between 30 and 40 years old based on the age, frequency of employees and most of the respondents held a degree of (high school degree, associate and master's degrees), and most respondents were the employees who have experience of between 10 and 15 years and had experience of over 20 years. The statistical results of all hypotheses were similar to the results of the studies by Kantek and Gezer (2009); Srivastava, (2009); Huang, (2010); Alzawahreh and Khasawneh, (2011); Salleh and Adulpakdee, (2012); Bibi et al., (2012); Römer et al (2012); Wamocha et al. (2012). Based on the results of this study and other researchers in the literature, all principles regardless of their demographic ingredient such as gender, experience, salary, workplace and education level use compromise and collaboration styles more than other styles. Principals should consider the problems clearly and not to hide them. This helps them to see all aspects of the problem and then find the best way to solve them.

Results of inferential statistics showed that for first hypothesis, there is no significant difference between the causes of organizational conflict based on the variable of gender. Therefore, the researcher hypothesized that there is no significant difference between the causes of organizational conflict based on the variable of gender is rejected. It seems that about gender across organizational role, the pattern of women is choosing problem-solving more than men and men choosing forcing more than women maintained regardless of organizational role. According to the results of Holt and Devore (2005), about gender comparisons, the results show differences in the self-reported use of compromising and forcing; however, compromising is the only style in which differences in gender exceed the study criteria for true differences. Females report using compromising more than men by a sizable margin. Such results support societal notions in the "United States" about gender differences, where women may be more likely than men to give up part of their own needs to compromise (Ting-Toomey \& Oetzel, 2003). There are no differences between women and men in reported use of smoothing and withdrawing, however, is contrary to popular notions that women are more willing to smooth over conflict or withdraw from it altogether (Holt \& DeVore, 2005). Research Sorensen et al. (1995) showed that women are more inclined than men to have more sense of style, but no significant differences between women and men founded on the use of conflict management styles. Perhaps it is also related to the type of organization (educational - scientific). 
According to the second hypothesis, there is a significant difference between the causes of organizational conflict based on the variable of age. Results of the One-way ANOVA test showed that there was a significant difference between the causes of organizational conflict based on the variable of age. There are many reasons for the differences in conflict studies at different ages listed, including increased experience, Physiological conditions, prevailing mental models and the focus on rationality.

Considering the third research hypothesis, there is a significant difference between the causes of organizational conflict based on the variable of education. The results of this hypothesis showed that there was a significant difference between the causes of organizational conflict based on the variable of education. The reasons for these issues were described in studies. Study by Smith and Magill (2009) pointed out that education might be a driver of conflict by fuelling grievances, stereotypes, xenophobia and other antagonisms. But it can also be a way of contributing to conflict transformation and peace building. According to Mitchell (2006), conflict is a necessary and inevitable dynamic in all human relationships. While, education gives awareness and opens up the mind and expands our horizons. Education spreads not only awareness but also informs us about our rights and the services that we can use. It also enables us to understand our duties as a citizen and encourages us to follow them. The relationship between educational development and conflict in a transitional stage of a society looks like an inverted $U$ shape (Mitchell, 2006). Though education creates some sort of misunderstandings or conflicts in the first development trajectory of the society, it resolves conflicts and brings a peaceful solution at the end when educational development of the society reaches a certain level (Dupuy, 2009). According to the fourth research hypothesis, there is a significant difference between the causes of organizational conflict based on the variable of work experience. Also the results of this hypothesis showed that there is a significant difference between the causes of organizational conflict based on the variable of work experience. There are varieties, levels of conflict occur at different levels of experience, and causes of conflict in the people are different. Because the work experience in the related field of conflict with the analysis or peace research or a conflict prevention, management \& resolution are different. Also knowledge of the dynamics of violent conflict in the IAU region and proven knowledge of the interaction between the environment, natural resources and climate in conflict and social change is in the different level. Finally, the experience in preparing working and policy response and possession of published work is dissimilar. This result was consistent with Johnson et al. (1997) study results.

Finally, we can conclude that conflict was an inevitable process in the organization and must manage, and each person may be involved with conflict in the workplace, according to conditions of gender, age, culture, occupation, etc. Therefore, according to the results of the study, managers recommended to decrease conflicts with emphasis on the main targets among the various levels based on incompatible goals. Also university managers should increase the 
organizational sense of loyalty in the employees and same opinion of employees with the targets of the university should use. About this issue, the following suggestions offered:

- In different values and beliefs, managers with job rotation between different sectors, decrease differences that had been the cause of conflict among the employees. Also, the university will attempt to clarify values, namely, clear and transparent values and beliefs of managers of university through briefings and communication between different levels, for every member of a university.

- Based on the ambiguity and role conflict, managers clearly and unambiguously express the duties and activities of employees until the stress caused by the ambiguity and role conflict is reduced. Also, managers of university should determine occupational expectations of the employee and avoid the conflicting commands.

- I n problems of communications, it is recommended to reduce conflict increasing informal communication such as joint meetings; sports venues, etc. and also employees should consider a personal communication method as important.

- Based on ambiguous rules, decision makers are recommended to clarify rules and procedures for making timely decisions and they also should review laws and regulations that will cause managers and employees not to show their activities if necessary.

- At authority conflict, job responsibility of university employees is commensurate with their authority, and any person carries out their responsibilities according to the scope of authority. In addition, managers and employees do not act outside the scope of his authority.

- Based on inconsistent evaluation and reward system, criteria and standards for payment of wages should be fair and equitable in the University. Namely, everyone has appropriate work to do to which his wages and bonus accrue.

- In Job stress, the University should implement welfare programs to reduce stress of employees. To implement these programs, issues related to employee's physical and mental condition should be taken into consideration. The psychological problems of employees should be solved if necessary.

- Based on task conflict, top management should clarify staff's clear and transparent responsibilities specify which employees do not act outside the scope of their duties and managers of each department should specify working tasks of employees.

Finally, regarding deficiency of information system, it is recommended that regular data should be updated in the information systems of organizations. In addition, some of the other results of 
this research showed that unfortunately, managers and employees in Iran, not only don't have a positive attitude toward organizational conflict in the field, they are also afraid of being introduced. Moreover the changing culture is an important factor in shaping employee behavior in the workplace, it is necessary to change the culture and long-term studies should be performed.

\section{References}

Akhoond lotfali, P., Hosseini, M.A., Khankeh, H.R., Fallahi Khoshknab, M., \& Hosseinzadeh, S. (2012). The effect of emotional intelligence education on job conflict in nurses. Journal of health promotion management (Iranian Journal), 1(1), 7-16. Available at: http://jhpm.ir/browse.php?a_code=A-10-23-2andslc lang=enandsid=1

Alzawahreh, A., \& Khasawneh, S. (2011). Conflict Management Strategies Adopted by Jordanian Managers based on Employees' Perceptions: the Case for the Manufacturing Industry. Institute of Interdisciplinary Business Research, 3(7), 147-166. Available at: http://www.eis.hu.edu.jo/deanshipfiles/pub104543226.pdf

Balay, R. (2006). Conflict management strategies of administrators and teachers. Asian Journal of Management Cases, 3(1), 5-24. http://dx.doi.org/10.1177/097282010500300103

BazarJazaeri, S.A. (1998). Skills of conflict management. Tadbir Journal (Iranian Journal), 79(1), 34-35.

Bibi, Z., Siraj, U.D., \& Nawaz, A. (2012). Demographic impacts on interpersonal conflict, mistreatment and discrimination: A survey of labor in public sector of Baluchistan, Pakistan. African Journal of Business Management, 6(35), 9823-9832. http://dx.doi.org/10.5897/AJBM11.2007

Cetin, M.O., \& Hacifazlioglu, O. (2004). Conflict Management Styles: A Comparative Study of University Academics and High School Teachers. The Journal of American Academy of Business, 5(1/2), 325-332.

Coleman, P.T. (2003). Characteristics of protracted, intractable conflict: Towards the development of a meta-framework - I. Peace and Conflict: Journal of Peace Psychology, 9(1), 137. http://dx.doi.org/10.1207/S15327949PAC0901_01

Corwin, R.G. (1969). Patterns of organizational conflict. Administrative Science Quarterly, 14, 507-520. Available at: http://www.jstor.org/stable/2391588 http://dx.doi.org/10.2307/2391588

Druckman, D., Broome, B.J., \& Korper, S.H. (1988). Value differences and conflict Resolution: Facilitation or delinking?. Journal of Conflict Resolution, 32(3), 489-510.

http://dx.doi.org/10.1177/0022002788032003005 
Dubrin, A.J. (1985). Contemporary Applied Management (2nd Ed.). Plano, Texas: Business Publications, 119-120. Available at: http://trove.nla.gov.au/version/22638891

DuBrin, A.J. (2005). Fundamentals of Organizational Behavior. (3rd Ed.). Canada: SouthWestern, Thomson.

Dupuy, K. (2009). Education in Peace Agreements, 1989-2005. Conflict Resolution Quarterly, 26(2), 149-166. http://dx.doi.org/10.1002/crq.228

Eder, P.P., \& James, F.J. (2002). Relationship between Demographic Characteristics and Conflict Handling Styles. The Center for Latin American Issues. The George Washington University. P. 27. Available at: http://www.gwu.edu/ clai/working papers/Paschoal Eder 05-02.pdf

Eliot, R.S. (1995). From stress to strength how to lighten your load and save your life. New York: Bantam, 276 pages.

Fisher, C.D., \& Gitelson, R. (1983). A meta-analysis of the correlates of role conflict and ambiguity. Journal of Applied Psychology, 68(2), 320-333.

Frederickson, J.D. (1998). Accessing the validity of the Rahim Organizational Conflict Inventory - II (ROCI-II). Unpublished doctoral dissertation, University of Minnesota.

Freeman, R.E., \& Gilbert, D.R. (1988). Corporate strategy and the search for ethics. Englewood Cliffs, NJ: Prentice-Hall. Available at: http://search.library.wisc.edu/catalog/ocm16922700

Gordon, A.G. (2008). Examining Conflict Management Style Preferences of Practitioner Faculty by Gender and Age. Northcentral University, ProQuest, 102 pages.

Guetzkow, H., \& Gyr, J. (1954). An analysis of conflict in decision-making groups. Human Relations, 7, 367-381. http://dx.doi.org/10.1177/001872675400700307

Havenga, W. (2002). Conflict management within a local government environment. MA dissertation, Potchefstroom University.

Hellriegel, D., Slocum J., \& Woodman, R.W. (1983). Organizational Behavior (3rd ed.). St. Paul, MN: West Publishing Co, 127-141.

Holt, J.L., \& DeVore, C.J. (2005). Culture, gender, organizational role, and styles of conflict resolution: A meta-analysis. International Journal of Intercultural Relations, 29(2), 165-196. http://dx.doi.org/10.1016/j.ijintrel.2005.06.002

Huang, J.C. (2010). Unbundling task conflict and relationship conflict: The moderating role of team goal orientation and conflict management. International Journal of Conflict Management, 21(3), 334-355. http://dx.doi.org/10.1108/10444061011063207 
İslamoglu, G., Boru, D., \& Birsel, M. (2008). Conflict management styles in relation to demographics. Boğaziçi Journal, 22(1-2), 107-140. Available at:

http://www.bujournal.boun.edu.tr/docs/13317355047.Guler\%20Islamoglu.pdf

Johnson, D.W., Johnson, R., Dudley, B., Mitchell, J., \& Frederickson, J. (1997). The impact of conflict resolution training on middle school students. Journal of Social Psychology, 137(1), 11-21. http://dx.doi.org/10.1080/00224549709595409

Kantek, F., \& Gezer, N. (2009). Conflict in schools: Student nurses' conflict management styles. Nurse Education Today, 29(1), 100-107. http://dx.doi.org/10.1016/j.nedt.2008.07.007

Kellermann, P.F. (1996). Interpersonal Conflict Management in Group Psychotherapy: An Integrative perspective. Group analysis, 29(2), 257-275.

http://dx.doi.org/10.1177/0533316496292012

Kreitner, R., \& Kinicki, A. (2001). Organizational behavior. New York: McGraw-Hill.

Krejcie, R.V., \& Morgan, D.W. (1970). Determining sample size for research activities. Educational \& Psychological Measurement, 30(3), 607-610. Available at: http://opa.uprrp.edu/InvInsDocs/KrejcieandMorgan.pdf

Mcshane, S.L., \& Travaglione, T. (2003). Organizational Behavior on the Pacific Rim. Sydney, NSW: McGraw Hill Australia. 1-672. ISBN/ISSN 0-074-71039-7.

Michel, J.S., Mitchelson, J.K., Kotrba, L.M., LeBreton, J M., \& Baltes, B.B. (2009). A comparative test of work-family conflict models and critical examination of work-family linkages. Journal of Vocational Behavior, 74(2), 199-218. http://dx.doi.org/10.1016/j.jvb.2008.12.005

Mitchell, P. (2006). Conflict regulation and party competition in Northern Ireland. European Journal of Political Research, 20(1), 67-92. http://dx.doi.org/10.1111/j.1475-6765.1991.tb00256.x

Mokhtarpour, S., Khademi, M., \& Mokhtarpour, H. (2013). Survey of relationship between principals' demographic characteristics and conflict management style choices. Journal of Advances in Medical Education and Professionalism, 1(2), 64-67. Available at: http://jamp.sums.ac.ir/index.php/JAMP/article/download/53/34

Parsaeian, A., \& Arabi, S.M. (1996). Organization; Structure, process and outputs. Tehran: No-bahar publication (Iranian Journal), 168-168.

Römer, M., Rispens, S., Giebels, E., \& Euwema, M.C.,(2012). A Helping Hand? The Moderating Role of Leaders' Conflict Management Behavior on the Conflict-Stress Relationship of Employees. Negotiation Journal, 28(3), 253-277. http://dx.doi.org/10.1111/j.1571-9979.2012.00340.x

Salleh, M.J., \& Adulpakdee, A. (2012). Causes of Conflict and Effective Methods to Conflict Management at Islamic Secondary Schools in Yala, Thailand. International Interdisciplinary Journal of Education, 1(1), 15-22. Available at: http://www.iijoe.org/IIJE 03 v1 i1 2012.pdf 
Seitz, K. (2004). Education and Conflict: The role of education in the creation, prevention and resolution of societal crises - Consequences for development cooperation. Eschborn: Deutsche Gesellschaft für Technische Zusammenarbeit (GTZ) GmbH - German Technical Cooperation.

Smith, A., \& Magill, C. (2009). Reconciliation, Does Education have a role? Shared Space: $A$ research journal on peace, conflict and community relations, 8(1), 5-15.

Sorensen, J.T., Campbell, B.C., Gill, R.J., Steffen-Campbell, J.D. (1995). Non-monophyly of Auchenorrhyncha ("Homoptera"), based upon 18S rDNA phylogeny: eco-evolutionary and cladistic implications with pre-Heteropteroidea Hemiptera (s.I.) and a proposal for new monophyletic suborders. Pan-Pacific Entomologist, 71(1), 31-60.

Srivastava, S. (2009). Organizational Variables and job stress: effect of moderating variables. Management \& Change, 13(2), 169-182.

Stubager, R. (2009). Education-based Group Identity and Consciousness in the AuthoritarianLibertarian Value Conflict. European Journal of Poltical Research, 48(2), 204-233. http://dx.doi.org/10.1111/j.1475-6765.2008.00834.x

Ting-Toomey, S., \& Oetzel, J. (2003). Cross-cultural face concerns and conflict styles: Current status and future directions. In Gudykunst, W.B. \& Mody, W.B. (Eds.). Handbook of International and Intercultural Communication (2nd ed., pp. 143-163). Thousand Oaks, CA: Sage.

VatanKhah, S., Raeisi, P., \& Kalhor, R.A. (2008). Correlation between Emotional Intelligence (EI) with Conflict Management Strategies in Managers of Qazvin Teaching Hospitals. Journal of Health Management (Iranian Journal), 11(32), 41-46.

Wall Jr, J.A., \& Callister, R.R. (1995). conflict and Its Management. Journal of Management, 21(3), 515-558. http://dx.doi.org/10.1177/014920639502100306

Wamocha, L.M, Nasongo, J.W. \& Injendi, J. (2012). Intervention Measures in Conflict Management in Boarding Secondary Schools in Western Province, Kenya. Current Research Journal of Social Science, 4(2). 103-108. Available at: http://maxwellsci.com/print/crjss/v4-103108.pdf

Journal of Industrial Engineering and Management, 2014 (www.jiem.org)

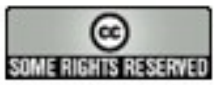

Article's contents are provided on a Attribution-Non Commercial 3.0 Creative commons license. Readers are allowed to copy, distribute and communicate article's contents, provided the author's and Journal of Industrial Engineering and Management's names are included. It must not be used for commercial purposes. To see the complete license contents, please visit http://creativecommons.org/licenses/by-nc/3.0/. 